\title{
MENTAL HEALTH EDUCATION AND PROFESSIONAL PRACTICE IN THE PSYCHIATRIC HOSPITAL ${ }^{1}$
}

\author{
João Mário Pessoa Júnior², Raionara Cristina de Araújo Santos ${ }^{3}$, Francisco de Sales Clementino ${ }^{4}$, Ellany Gurgel \\ Cosme do Nascimento ${ }^{5}$, Francisco Arnoldo Nunes de Miranda ${ }^{6}$
}

1 This study was extracted from the dissertation - Profiles and practice of mental health professionals in psychiatric hospitals, presented
at the Programa de Pós-Graduação em Enfermagem (PPGEnf), Universidade do Estado do Rio Grande do Norte (UFRN), in 2014.
2 Ph.D. in Nursing. Professor, Universidade Federal do Rio de Janeiro. Macaé, Rio de Janeiro, Brazil. E-mail: joaomariopesssoa@gmail.
com
${ }^{3}$ Ph.D. in Nursing. Ribeirão Preto, São Paulo, Brazil. E-mail: raionara_cristina@yahoo.com.br
${ }^{4}$ Ph.D. in Nursing. Professor, Universidade Federal de Campina Grande. Campina Grande, Paraíba, Brazil. E-mail: fclementino67@
yahoo.com.br
${ }^{5}$ Ph.D. in Health Sciences. Professor, Departamento de Enfermagem, UFRN. Pau dos Ferros, Rio Grande do Norte, Brazil. E-mail:
ellanygurgel@hotmail.com
${ }^{6}$ Ph.D. in Nursing. Professor, Departamento de Enfermagem, UFRN. CNPq scholarship. Natal, Rio Grande do Norte, Brazil. E-mail:
farnoldo@gmail.com

ABSTRACT: This study aimed at identifying the opinion of professionals about mental health education and professional practice in the psychiatric hospital. It is a descriptive, exploratory study with qualitative approach, developed with 60 professionals of higher education in two psychiatric macro-hospitals in Rio Grande do Norte. Data were collected through a questionnaire, then transcribed, processed according to the Alceste software and subjected to content analysis. The results were structured in two thematic axes and their respective themes: thematic axis 1 - Professional practice in mental health, and thematic axis 2 - Mental health education. The confluence of asymmetries and differences in the performance of the teams in the psychiatric hospital were evident. The resulting scenario reflects the current political and ideological discrepancy of the current Brazilian process of Psychiatric Reform, considering the challenges of implementation and professional qualification in the field of psychosocial care.

DESCRIPTORS: Mental health services. Human resources. Education. Mental health. Nursing.

\section{FORMAÇÃO EM SAÚDE MENTAL E ATUAÇÃO PROFISSIONAL NO ÂMBITO DO HOSPITAL PSIQUIÁTRICO}

\begin{abstract}
RESUMO: Objetivou-se identificar a opinião de profissionais sobre formação em saúde mental e a atuação profissional no âmbito do hospital psiquiátrico. Estudo descritivo, exploratório, de abordagem qualitativa, desenvolvido com 60 profissionais de nível superior em dois macro-hospitais psiquiátricos do Rio Grande do Norte. Os dados foram coletados por meio de um questionário, em seguida, transcritos, processados conforme do software Alceste e submetidos à análise de conteúdo. Os resultados foram estruturados em dois eixos temáticos e seus respectivos temas: eixo temático 1 - Atuação profissional em saúde mental e eixo temático 2 - Formação em saúde mental. Evidenciou-se a confluência de assimetrias e divergências na atuação das equipes em hospital psiquiátrico. O cenário encontrado reflete o descompasso político e ideológico atual do processo brasileiro de Reforma Psiquiátrica, considerando-se os desafios de implementação e qualificação profissional no campo da atenção psicossocial.
\end{abstract}

DESCRITORES: Serviços de saúde mental. Recursos humanos. Educação. Saúde mental. Enfermagem.

\section{EL PROCESO DE FORMACIÓN EN SALUD MENTAL Y LA ACTUACIÓN PROFESIONAL EN EL HOSPITAL PSIQUIÁTRICO}

\begin{abstract}
RESUMEN: Se objetivó identificar la opinión de los profesionales sobre la actuación en salud mental y la formación profesional en el ámbito de los hospitales psiquiátricos. Estudio descriptivo, exploratorio de abordaje cualitativo, desarrollado junto a 60 profesionales de nivel superior en dos macros hospitales psiquiátricos del Rio Grande do Norte. Se recolectaron los datos por medio de un cuestionario, los cuales fueron transcritos y procesados a través del software Alceste y sometidos a análisis de contenido de Bardin. Los resultados fueron estructurados en dos ejes temáticos y sus respectivos temas: Eje temático 1- actuación profesional en salud mental y; Eje temático 2- "Formación en salud mental". Se evidenció la confluencia de asimetrías y divergencias en la actuación de los equipos en el hospital psiquiátrico. El escenario encontrado refleja la actual coyuntura política e ideológico del proceso de Reforma Psiquiátrica brasileño, considerándose los desafíos de implementación y capacitación profesional en el campo de la atención psicosocial.
\end{abstract}

DESCRIPTORES: Servicios de salud mental. Recursos humanos. Educación. Salud mental. Enfermería. 


\section{INTRODUCTION}

The psychiatric model used to focus on the expansion of psychiatric hospitals and the creation of nursing homes, marked by an excluding health service, taking into consideration the high number of inpatients and people abandoned by families, which was a reason for criticism and international reports at the time. ${ }^{1}$ Thus, it elapsed the historical and institutionally elaborated conception of mental health practices in this model of nursing homes and asylums, with results in the human resources training process and in the practice of professionals inserted in these areas. ${ }^{2}$

In Brazil, a change of scenery was especially prompted with the origin of the Unified Health System (SUS), the Psychiatric Reform movement and the National Mental Health Policy (Politica Nacional de Saúde Mental, PNSM), directly influencing teaching and training of human resources in the mental health area. ${ }^{3}$ This reality resulted in the need for the implementation of teaching practices, research and extension - by Universities and educational centers - which would cover the dynamics of society.-5

Moreover, professional practice in mental health was rethought, and its insertion in the new mental health services was initiated. There was, therefore, investment in the professionals' experience and qualification to work in many of the different mechanisms of the Psychosocial Care Network's (Rede de Atenção Psicossocial, RAPS), including the Psychosocial Care Centers (Centros de Atenção Psicossocial, CAPS), therapeutic homes, day-hospitals, among others, where the daily practice resulted in the need for different forms of interdisciplinary work to intervene and to take care of the mentally ill individual. ${ }^{6}$

In the psychosocial care model, singular importance is attributed to collective practices and to the logic of interdisciplinary work, in a performance model that assumes the horizontality of relationships and involves the family and the user during treatment. Thus, the emerging need for professionals to recognize care centered on people's development and psychosocial rehabilitation, focusing on practices based on PNSM principles. ${ }^{7}$

The important role of Universities and excellence centers in the Psychiatric Reform process is acknowledged, as well as the transition from a standard asylum disorder treatment to a psychosocial care model, with community foundations, taking into account the relevant contribution of pedagogical practices, widespread among the undergraduate courses in the health area. ${ }^{3-5}$ In this model, nurses, doctors, psychologists, social workers, and others, are important agents in the implementation of better assistance to people with mental disorders and in the implementation of public policies on mental health.

Considering the expansion scenarios of public services specialized in mental health among Brazilian regions, it is clear the reduced amount of training and professional development courses, which reflects in lack of qualified professionals in the area. ${ }^{4-5}$ Among the undergraduate courses in health area - such as nursing and medicine - the disciplines, the theoretical and practical hours intended for mental health are reduced due to all the complexity that they encompass. In addition, there are limitations imposed by the training process which transits between the biological technical model and humanistic training. ${ }^{8}$

There are also challenges linked to professional activities among the various services, including attention to mental health - such as the poor structure of services, shortage of qualified personnel, lack of an interdisciplinary teamwork, remnants of the asylum model in everyday professional practice and the lack of articulation between the substitutive services and the psychiatric hospital. ${ }^{9}$

From the assumption that training and qualification of professionals influence their practices and mental health care, the study aims at identifying the opinion of these professionals on this subject in the psychiatric hospital.

\section{METHOD}

This is a descriptive study with qualitative approach, developed with 60 professionals (nurses, social workers, psychologists, doctors, occupational therapists, and physical education teachers). The survey took place in two large public psychiatric hospitals in the State of Rio Grande do Norte (RN). The first one is located in the capital and has 130 beds. The second, in the countryside, has 200 beds.

The following inclusion criteria were adopted: a higher education professional with a permanent full time job, experience of at least six months in the public mental health service, and having provided care to users and their families. Thus, it aimed at encompassing a greater number of subjects among all the higher education categories present in both institutions. Therefore, in the first hospital, 41 out of 60 professionals took part in the study: 17 nurses, three doctors, nine psychologists, six occupational therapists and six social workers. And, in the second one, 19 out of 35 professionals were included: 
five nurses, six psychologists, three occupational therapists, three social workers and two physical education teachers.

Data collection took place from June to October 2014, through the use of a self-administered questionnaire containing close-ended questions about socio-demographic aspects of the participants and six questions about health training and professional practices at service. Initially, coordinators of each service were personally contacted in order to clarify details about the research, such as inclusion in the field, subjects' inclusion criteria, and others. In addition, there was an official contributor in each place. They were professionals from the service itself, which contributed directly to the collection stage, considering the shift scheme developed by them.

Delivery of questionnaires took place at the workplace, taking into account the professional's availability and interest in participating and the shift with less activity stream. The objective of the research and further guidance about the instrument were explained to participants as they received it, reinforcing ethical precepts. Apart from that, it was self-administered. After doubts were clarified, each one was requested to read and signed an Informed Consent Form.

Following the questionnaires' application and collection, data were transcribed and a database was thus formed. It was then submitted to thematic content analysis, with the aid of software named Analyse Lexicale par Contexte d'un Ensemble de Segment de Texte (Alceste) 4.8, a program that fragments the text, lays out the similarities between the segments and hierarchies of words' classes. In general, Alceste identifies words and their roots, forming a dictionary. It divides the discursive material in elementary context units (Unidades de Contexto Elementares, UCEs); delimits semantic classes and describes them by the quantification of reduced forms and function of UCEs, as well as the links established between them. It analyzes the association and correlation of variables reported to classes obtained; and, finally, it investigates the established links between the typical words depending on the classes (dendrogram). ${ }^{10}$

The following steps took place during the analysis stage: a) pre-analysis, organization time and reading of transcribed material (analysis plan); b) material exploration, time to codify relevant quotations from Alceste 4.8 to the purpose of the study; and c) interpretation and treatment of findings resulted from the program. The thematic categories resulting from this stage were discussed based on official documents and specific literature on the topic.
The material obtained through Alceste generated a corpus consisting of 312 initial context units (Unidades de Texto Iniciais, UCIs), resulting in the selection of 318 UCEs, with use of $49 \%$ of the UCEs selected (not very conclusive or specific affirmative answers to questions proposed), obtaining five different and interconnected classes. This corpus was composed by 1,178 distinct words. The words with frequency equal or less than 4 , and chi-square less than 3.84 were discarded. The classes 2,3 and 4 were used, since they specifically depicted the training process in health and professional performance, the object of the study. Data obtained from the classes were subjected to exhaustive and interpretive reading, with the aid of thematic content analysis. ${ }^{11}$

The research project was approved by the Etichal Research Committee of the UFRN, under the number 508,430, CAAE: 25851913.7.0000.5537, in line with the ethical precepts of Resolution $466 / 2012$. To ensure the confidentiality and anonymity of the participants, excerpts from speeches were identified by professional category, followed by sequential numbering of the study subjects.

\section{RESULTS}

Respondents of the survey were predominantly female, professional nurses aged 50 to 59 years old; graduation time of 34 years, and 35 years on mental health work, out of which, 12 were specialized in mental health.

Two major thematic axes and their respective themes were organized through the findings analysis process, namely: Thematic axis 1 - Professional practice in mental health, and its three themes: Professional service: patient as priority; Teamwork: promoting interaction; and Psychiatric Hospital X psychosocial care. Thematic axis 2 - Mental health education, was subdivided into two themes: Limitations on academic training; and Continuing education: barriers and priorities (Figure 1).

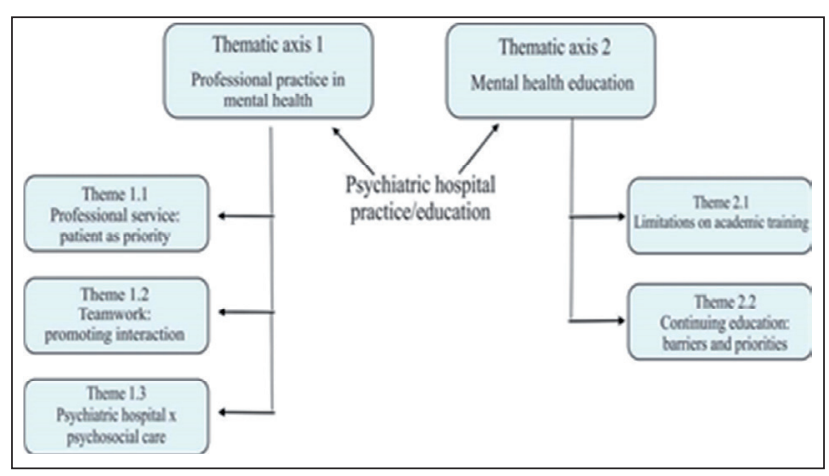

Figure 1 - Axies and study themes. Natal-RN, 2014 
In Table 1, the highlighted theme was Professional practice in mental health, corresponding to the first results' axis and its three respective sub- themes, besides some selected excerpts obtained from responses of health professionals.

\section{Table 1 - Thematic axis 1 - Professional practice in mental health. Natal-RN, 2014}

\begin{tabular}{|c|c|c|}
\hline $\begin{array}{c}\text { Professional service: patient as } \\
\text { priority }\end{array}$ & Teamwork: promoting interaction & Psychiatric hospital x psychosocial care \\
\hline $\begin{array}{l}\text { I try to do my job, focusing at the patient } \\
\text { first (Nurse 9). }\end{array}$ & $\begin{array}{l}\text { To act alongside with other mental health } \\
\text { professionals to promote patients rehabili- } \\
\text { tation in cognitive and social aspects (Oc- } \\
\text { cupational therapist 3). }\end{array}$ & $\begin{array}{l}\text { The substitute services do not supply the de- } \\
\text { mand properly. Besides, there is the stigma } \\
\text { that patient, family and professionals are ex- } \\
\text { posed to (Psychologist } 8 \text { ). }\end{array}$ \\
\hline $\begin{array}{l}\text { Individual or in-group reception for } \\
\text { patients, respecting their limitations, } \\
\text { seeking their well-being as service user } \\
\text { (Psychologist 10). }\end{array}$ & $\begin{array}{l}\text { We seek to act ethically and responsibly, } \\
\text { with humanized attitudes, aiming at im- } \\
\text { proving the relationship among the team } \\
\text { professionals and respecting the patient } \\
\text { (Psychologist 8). }\end{array}$ & $\begin{array}{l}\text { Discuss about the patient's therapeutic pro- } \\
\text { ject, open spaces for patients' autonomy, res- } \\
\text { pect their rights and singularities, and stren- } \\
\text { gthen patients' links with CAPS services etc. } \\
\text { (Social worker 3). }\end{array}$ \\
\hline $\begin{array}{l}\text { Patient and family support, trying to sol- } \\
\text { ve the problem where they get ill (Social } \\
\text { worker 8). } \\
\text { To provide emotional support to patient } \\
\text { and family, relieving their treatment and } \\
\text { helping them to cope with their illness } \\
\text { whenever possible (Psychologist 5). } \\
\end{array}$ & $\begin{array}{l}\text { If there was greater involvement of em- } \\
\text { ployees in performing team work, as well } \\
\text { as the understanding that this form of in- } \\
\text { tervention benefits the patient, favoring } \\
\text { him in all aspects, the patient care service } \\
\text { would be better } \\
\text { (Occupational therapist 6). }\end{array}$ & $\begin{array}{l}\text { We have to face different and wrong ways to } \\
\text { handle mental illness, the precariousness of } \\
\text { out-of-hospital service network and different } \\
\text { degrees of professional commitment (Social } \\
\text { worker 1). }\end{array}$ \\
\hline $\begin{array}{l}\text { To collaborate with other professionals } \\
\text { aiming at contributing and improving } \\
\text { users' quality of life and the recovery } \\
\text { process (Social worker 9). }\end{array}$ & $\begin{array}{l}\text { I think there is still a lot to be done in } \\
\text { order to consider the unified work as sa- } \\
\text { tisfactory. It is still not possible to see an } \\
\text { integrated team (Psychologist 10). }\end{array}$ & $\begin{array}{l}\text { I have been insisting that, despite the difficul- } \\
\text { ties and obstacles, patients are not so depen- } \\
\text { dent on the hospital and have the possibility } \\
\text { of being reintegrated to society and families } \\
\text { (Psychologist 5). }\end{array}$ \\
\hline
\end{tabular}

Table 2 summarizes the second thematic axis of the study named Mental health education with its two sub-themes; and contains excerpts with answers from professionals.

\section{Table 2 - Thematic axis 2 - Mental health education. Natal-RN, 2014}

\begin{tabular}{|c|c|}
\hline Limitations on academic education & Continuing education: barriers and priorities \\
\hline $\begin{array}{l}\text { There is no specific discipline on mental health in social service edu- } \\
\text { cation (Social worker } 7 \text { ). }\end{array}$ & Lack of expertise and training in mental health team (Nurse 18). \\
\hline We had no training in this area at College (Psychologist 9). & $\begin{array}{l}\text { There are not many courses offered to the hospital. Training } \\
\text { courses are destined to CAPS, favoring the professionals who } \\
\text { work in these services (Social worker 9). }\end{array}$ \\
\hline tarting from mental health workload, which & $\begin{array}{l}\text { working process, activities carried } \\
\text { t to the lack of training, participa- } \\
\text { 11). }\end{array}$ \\
\hline $\begin{array}{l}\text { The in } \\
\text { cially }\end{array}$ & o looking for professional improve- \\
\hline The University invests little in mental health education (Nurse 8). & $\begin{array}{l}\text { I try to keep updated with mental health and therapeutic policies } \\
\text { (Nurse). }\end{array}$ \\
\hline $\begin{array}{l}\text { We have no ment } \\
\text { cial worker 2). }\end{array}$ & $\begin{array}{l}n \text { for updating and improve } \\
\text { apist 3). }\end{array}$ \\
\hline
\end{tabular}

\section{DISCUSSION}

Driven by the Psychiatric Reform process and the PNSM, the current Brazilian scenario of changes in mental health service production in psychosocial care context, requires a complex combination of knowledge, practices and interventions from the professionals. Those interventions were before focused on the repressor asylum model. Now, they need to be replaced for new therapeutic ones 
when dealing with madness $\backslash$ mental illness, and the person with mental disorder. In this sense, reflexes and challenges are determined for human resources training in this area. ${ }^{1-5}$

Data resulting from the structuring of the first axis and its themes point out that, professional practice, in the Psychiatric Hospital context, prioritizes the individual patient and family, in the emotional support and care perspective. Concerns of quality of life and social inclusion of treated patients also emerged, revealing a different approach, even when considering the specificity of the hospital institution.

Professional activity contextualized to PNSM requires attention, promotion of mental health practices to ensure the de-institutionalization and recovery of patients' citizenship. This movement must be mediated not only by the technical and intellectual capacity to act politically in face of working processes in hospital environment, but by the ability to recognize an integral care to patients with mental disorders and their families. ${ }^{2}$

In the mental health care context, teamwork emerged as a fundamental and challenging element in the institution, where the promotion of interaction between the various professionals at service was possible, thus reinforcing interpersonal relationships as a way to contribute towards professional-patient bonding. It was also mentioned that the humanized approach in patient care should be thought as an ethical and human value, i.e., the team member's commitment at service.

The logic of teamwork organization in mental health tries to break this conception of fragmented assistance and the rigidity still present in services, which, in most cases, ends up producing adverse effects in the treatment of mentally ill. ${ }^{7,12}$ Despite these projections, there are still obstacles and difficulties in working processes reorganization with the focus at the Psychiatric Reform principles implementation in Brazil. Furthermore, tensions coexist in the definition of roles and knowledge among professionals in face of the new mental health devices. ${ }^{13}$

A study ${ }^{14}$ performed about teamwork in a CAPS located in the municipality of Rio de Janeiro, which aimed at investigating the possibilities and obstacles of interdisciplinary integration, identified asymmetries between the disciplines and the difficulties in communication among working professionals. Among possibilities of the interdisciplinary proposal, group activities, micro meeting and team meetings among the experts were highlighted. Interdisciplinarity is promoted as strategic in the context of working with teams, because it encompasses the knowledge exchange process and a deeper, more coordinated integration between disciplines. ${ }^{14}$

Thus, it is understood that mental health professionals' performances suffer direct influence from teamwork process, either multidisciplinary or interdisciplinary. In view their specific nature, insertion and professional performance within the health team (either a nurse, doctor, social worker, psychologist, or others) define above all the conduct and performance of their professional daily practice, as well as the theoretical foundation in which it is based and the model to intervene in this regard. ${ }^{7}$

On the axis Psychiatric hospital X psychosocial care, it was observed that professionals mapped the main obstacles to psychiatric hospital care as well as to other services that make up the mental health network. Problems associated with lack of physical structure, shortage of materials and medicines, and high demand of patients were pointed out at service. Difficulties were also reported in the extra-hospital network, such as reduced number of vacancies, work in the singular therapeutic project, and even the need to strengthen the connection between CAPSs and patients.

Psychiatric hospitals compose the network of psychosocial care and are responsible for much of the service performed in emergency mental health. However, they were displaced from attention in the public policy area under the constant idea of phasing out. Even with the quantitative expansion process of substitute services, especially the CAPSs, it is clear that the existence of structural and political problems directly influence on the quality of professional care.

In an evaluation study ${ }^{15}$ developed in the CAPSs, operational and resolution problems were identified, indicating improvement needed in care strategies, and investment in staff and spare beds. Greater governmental investment and accountability was pointed out as necessary in the constitution and training of teams, and effective increase in population coverage with larger number of community services and beds. ${ }^{15}$

The implementation of an articulated and horizontal service network is known to allow continuous dialogue among its various services and mechanisms. Moreover, it is able to provide greater coverage of mental health actions in the territory and, therefore, to promote an effective dialogue with other social sectors. The aim is to deconstruct hierarchical and organizational asymmetries in relations established over the years among the services. ${ }^{6}$ In this way, the traditional idea of "gateway" is broken, allowing the 
user multiple possibilities of flow within the network. In addition, it strengthens the knowledge exchange between healthcare professionals in different levels of complexity in the health system. ${ }^{6}$

The growing need to specialize assistance, leads to rethinking the process of professional training for development of skills and competencies in face of the challenges and changes arising with the Psychiatric Reform and the new logic of psychosocial care network. The second thematic axis points to the debate over mental health training. The first theme focused on the limitations of professional's academic education in the area, such as insufficient theoretical-practical workload and inferior than other disciplines; some pointed out to the lack of discussions on mental health in undergraduate courses, and reinforced the lack of instrumentation from the University in the area.

In the Brazilian educational context, the Law of Directives and Bases of National Education (Lei de Diretrizes e Bases da Educação Nacional, LDB) and the National Curricular Guidelines for undergraduate courses promoted changes in education. These changes directed actions aimed at the teaching projects reform, and flexibility of courses' curriculums, promoting an education that contributes to develop technical, cultural and scientific skills in people, so that they can actively participate in their social reality. ${ }^{16}$ This change, however, is slow and asymmetric, particularly among courses of the health area, where the hegemony of the biological and drug-based model is clear, focusing on the disease. This fact is also observed in other studies. $5,8,12$

Considering the highlighted limitations in training, the second theme addresses permanent education in mental health as a strategic resource for overcoming the dichotomies that exist between knowledge and professional action. Professionals identified it as important; most of them saw as a necessity, however, it is not implemented as an active institution policy. The lack of training and courses in this area, particularly intended for the Psychiatric hospital, is evident.

The Permanent Education Policy in Health (Política de Educação Permanente em Saúde) was established in Brazil with the aim of transforming the pedagogical and health practices through the training of performances and services, and to contribute to both individual and collective development processes of health professionals. In the mental health framework, PNPS should be articulated to PNSM as guiding axis of the training and specializing process. That would strengthen, amongst undergraduate students, the inter and multidisciplinary work ideal, where professionals transcend the condition from a passive subject to the leading role in the training process, with competence to perform throughout the various care devices, from CAPSs and primary care to hospital assistance.

\section{FINAL CONSIDERATIONS}

The findings of this study suggest the confluence of asymmetries and differences in the performance of the psychiatric hospital teams with the implementation of new public policies for the area, despite changes identified in the practice context in mental health care services. The scenarios evidenced here partly reinforce the political and ideological of Brazilian Psychiatric Reform current process mismatch in face of the challenges to its implementation and to professional training in the psychosocial care area.

Training process in mental health - either academic training or even capacitation strategies and improvement in services - in the form of permanent education is appointed as the driving force for overcoming the listed challenges, among which, teamwork implementation and its best action and articulation in the psychosocial scenario. There is an urge for greater efforts to encourage improvement in mental health training, so that it is directed to professionals, as a strategy for strengthening public policies and interventions in the area, and above all, to consolidate innovative and permanent education practices among services.

\section{REFERENCES}

1. Duarte SL, Garcia MLT. Reforma psiquiátrica: trajetória de redução dos leitos psiquiátricos no Brasil. Emancipação. 2013; 13(1):39-54.

2. Cardoso L, Galera SFA. O cuidado em saúde mental na atualidade. Rev Esc Enferm USP [Internet]. 2011 [cited 2015 Jul 01]; 45(3):91-107. Available from: http:/ / www.scielo.br/pdf/reeusp/v45n3/v45n3a20.pdf

3. Dal Poz MR, Lima JCS, Perazzi S. Força de trabalho em saúde mental no Brasil: os desafios da reforma psiquiátrica. Physis, Rev Saúde Coletiva [Internet]. 2012 [cited 2015 Jul 05]; 22(2):621-39. Available from: http:/ / www.scielo.br/pdf/physis/v22n2/12.pdf

4. Dias CB, Aranha e Silva AL. O perfil e a ação profissional da(o) enfermeira(o) no Centro de Atenção Psicossocial. Rev Esc Enferm USP [Internet]. 2010 [cited 2015 Jul 05]; 44(2):469-7. Available from: http:/ / www.scielo.br/pdf/reeusp/v44n2/32.pdf

5. Barros S, Claro HG. Processo ensino-aprendizagem em saúde mental: o olhar do aluno sobre reabilitação 
psicossocial e cidadania. Rev Esc Enferm USP [Internet]. 2011; 45(3):700-7. Available from: http:/ / www.scielo.br/pdf/reeusp/v45n3/v45n3a22.pdf

6. Pinto DM, Jorge MSB, Pinto AGA, Vasconcelos MGF, Cavalcante CM, Flores AZT, et al. Projeto terapêutico singular na produção do cuidado integral: uma construção coletiva. Texto Contexto Enferm [Internet]. 2011 [cited 2015 Jul 05]; 20(3):293-302. Available from: http://www.scielo.br/pdf/tce/v20n3/10.pdf

7. Verhaak PF, Prins MA, Spreeuwenberg P, Draisma S, Van Balkom TJ, Bensing JM, et al. Receiving treatment for common mental disorders. Gen Hosp Psychiatry. 2009; 31(1):46-55.

8. Soares NA, Silveira BV, Reinaldo MAS. Serviços de saúde mental e sua relação com a formação do enfermeiro. Rev Rene. 2010; 11(3):47-56.

9. Pinho LB, Banon Hernández AM, Kantorski LP. Trabalhadores em saúde mental: contradições e desafios no contexto da reforma psiquiátrica. Esc Anna Nery Rev Enferm [Internet]. 2010 [cited 2013 Mar 16]; 14(2):260-7. Available from: http://www. revistaenfermagem.eean.edu.br/detalhe_artigo. asp?id $=535$

10. Azevedo DM, Costa RKS, Miranda FAN. Use of the Alceste in the analysis of qualitative data: contributions to researches in nursing. J Nurs UFPE on line [Internet]. 2013 [cited 2015 Mar 16]; 4(esp):501522. Available from: http://www.revista.ufpe.br/ revistaenfermagem/index.php/revista/article/ download/3297/6801
11. Bardin L. Análise de conteúdo. Lisboa (PT): Edições 70; 2009.

12. Mitre SM, Siqueira-Batista R, Girardi-de-Mendonça JM, Morais-Pinto NM, Meirelles CAB, Pinto-Porto C, et al. Metodologias ativas de ensino-aprendizagem na formação profissional em saúde: debates atuais. Ciênc Saúde Coletiva [Internet]. 2008 [cited 2015 Mar 16]; 13(Sup 2):2133-44. Available from: http:/ / www. scielo.br/pdf/csc/v13s2/v13s2a18.pdf

13. Lima RVM, Pedrão LJ, Gonçalves JG, Luis MAV. Papéis, conflitos e gratificações do enfermeiro de serviços abertos de assistência psiquiátrica. Rev Eletr Enf [Internet]. 2010 [cited 2015 Mar 16]; 12(2):348-53. Available from: http://www.fen.ufg.br/revista/v12/ n2/v12n2a19.htm

14. Vasconcellos VC. Trabalho em equipe na saúde mental: o desafio interdisciplinar em um CAPS. SMAD Rev Eletr Saúde Mental Álcool e Drogas [Internet]. 2010 [cited 2015 Mar 16]; 6(1):1-16. Available from: http://www.revistas.usp.br/smad/ article/view/38712/41563

15. Conselho Regional de Medicina do Estado de São Paulo. Avaliação dos Centros de Atenção Psicossocial (CAPS) do Estado de São Paulo. São Paulo: CREMESP; 2010.

16. Brasil. Lei n. 9.394 de 20 de dezembro de 1996 (BR). Estabelece as diretrizes e bases da educação nacional. Diário Oficial da União. 23 dez 1996. Brasília. Constituição da Republica Federativa do Brasil. Brasília (DF): Senado; 1996. 